This is a pre-copyedited, author-produced version of an article accepted for publication in Journal of the History of Medicine and Allied Sciences following peer review. The version of record: Joseph, M., 'Military Officers, Tropical Medicine, and Racial Thought in the Formation of the West India Regiments, 1793-1802', J Hist Med Allied Sci. Advance Access published October 28, 2016, doi: $10.1093 / \mathrm{jhmas} / \mathrm{jrw} 037$ is available online at:

http://jhmas.oxfordjournals.org/content/early/2016/10/27/jhmas.jrw037.short?rss=1 (28 October 2016).

\title{
Military Officers, Tropical Medicine, and Racial Thought in the Formation of the West India Regiments, 1793-1802
}

\section{Abstract}

The article examines the establishment and growth of the West India Regiments, British army corps manned by slaves of African descent and commanded by European officers, between 1793 and 1802. Focusing on the medical history of British military operations in the West Indies, the article demonstrates that the rationale behind the regiments was medical, but that the impetus for them came from senior military commanders rather than from the medical practitioners whose writings are usually privileged in the historiography. The senior officers who commanded the West Indian expeditions in the French Revolutionary Wars mobilized their own particular brand of medical theory, explicitly based on their own experience of the region's epidemiological environment, in support of the policy. This willingness to adopt and adapt medical ideas heavily influenced both military policy regarding the regiments, and commanders' relationships with their medical men. Key words - military medicine, West Indies, French Revolutionary Wars, race, slavery, observation, experience, yellow fever, tropical medicine.

\section{Introduction}

In a letter dated 22 December 1794, the commander-in-chief of the British army in the Windward and Leeward Islands, Sir John Vaughan, requested permission to raise a new body of men, the likes of which the region had never seen before: 
I am of opinion [sic] that a Corps of one thousand Men composed of blacks and Mulattoes, and commanded by British Officers, would render more essential service in this Country, than treble the number of Europeans who are unaccustomed to the Climate. And as the Enemy have adopted this measure to recruit their Armies, I think we should pursue a similar plan to meet them on equal terms. ${ }^{1}$

Arriving to replace Sir Charles Grey in October 1794, Vaughan had found that the so-called "sickly season" had whittled his available force down to just 1509 European troops, with another 1189 listed as sick. ${ }^{2}$ Worse still, the glorious beginning to Grey's 1793-1794 expedition, lauded in The Times as having permanently destroyed French commercial power in the region, seemed a distant memory; subsequent slave insurrections, partly orchestrated by French agents, had restricted British control to the major urban centres in most of the newly-conquered islands. ${ }^{3}$ With reinforcements uncertain, and the islands of Antigua, St. Kitts, Barbados, and Tobago all left without a single British soldier, Vaughan's proposal appears to have been the only plausible solution to a situation which was becoming increasingly critical. Initially appearing in locally-raised private bodies, for the first time ever black men were gradually taken onto the British establishment as full soldiers in corps which became known as the West India Regiments (WIR). ${ }^{4}$ Finding the colonial legislatures unwilling to grant their slaves for such a purpose, the government was forced to change tack, ultimately buying an estimated 13,400 slaves for the WIR between 1795 and 1808 at a cost of about $£ 925,000$; this made it perhaps the largest individual purchaser of slaves in the build-up to abolition. ${ }^{5}$

In spite of some recent interest, the historiographical treatment of British military medicine in the West Indies remains patchy. ${ }^{6}$ If the insights of environmental and biological history have established that high mortality was an inevitable corollary of European military activity in the region, this basic fact too often forestalls extended analysis. ${ }^{7}$ Beginning with Sir John Fortescue's dismissal of Britain's campaigns in the "pestilent islands," the bulk of the historiography has only rarely attempted to understand European mortality in terms of contemporary medical thought. ${ }^{8}$ Through the lens of this 
presentism, military medicine becomes equal parts tragedy and farce, a tale of helpless doctors, ignorant generals, and thousands of pointless deaths. ${ }^{9}$

It is, however, well understood among historians of medicine that this bungling caricature fails to do justice to the military and naval practitioners of the era. Institutional histories of the Army Medical Department have long shed valuable light on the administrative and technical developments driven by the French Revolutionary and Napoleonic wars. ${ }^{10}$ Such studies have been complemented in more recent years by works which deal with the social and professional milieu occupied by military physicians and surgeons, thereby establishing the interconnectedness of the military and civilian medical worlds. ${ }^{11}$ Indeed, historians have increasingly come to see that Britain's armed forces acted as the main conduit through which medical knowledge and new forms of empirical reasoning were generated in the tropics and transmitted back to Europe. As Mark Harrison has noted, the unprecedented opportunities for pathological investigation offered by military service in the West Indies meant that morbid anatomy had become "the foundation of aetiology and therapeutics in the tropics long before British doctors ever dreamt of walking the wards in Paris." ${ }^{12}$

Military officers are viewed as marginal to these histories, largely intervening only to risk catastrophe by manifestly ignoring the advice of their medical men. An examination of the creation of the WIR, however, urges us to reconsider this view. The regiments have hitherto escaped sustained treatment in the historiography, the most notable exception being Roger Buckley's Slaves in Red Coats and, although here and elsewhere the analysis has been underpinned by a recognition of the medical context, the reasoning invoked has generally been of a fundamentally modern character. This is to say that an equation which takes the creation of the WIR as the sum of European mortality and differential immunity (itself an anachronism) relies on a modern aetiology of yellow fever and malaria rather than an eighteenth-century understanding of disease. Where contemporary theory has been addressed, historians have focused on a limited intellectual canon of medical texts by the likes of John Hunter, Colin Chisholm, and William Fergusson. ${ }^{13}$ Michael Duffy's 
excellent military account of the West Indies in the French Revolutionary Wars exemplifies this stark separation of the military and the medical, viewing the WIR as an issue of manpower for which a medical explanation was only later imported, as if the idea of military commanders producing a medically-grounded decision is inconceivable. ${ }^{14}$

This article, however, argues that the main impetus for the WIR came from a succession of commanders-in-chief, and that it is thus to their correspondence that we must turn if we are to understand the origins of the regiments. In doing so, it seeks to make a broader point about military medicine, arguing that military commanders could and did independently mobilize medical thought during this period, neither remaining entirely ignorant of nor simply parroting the ideas which historians have come to view as constituting contemporary medical theory. The article focuses on the Windward and Leeward Islands from the beginning of the wars in 1793 through to 1802; Saint Domingue is omitted, being a separate and secondary command to that under which the WIR were raised. Senior commanders' demands for black troops were centred on the vulnerabilities they observed in their white forces, and thus analysing the medical rationale behind the WIR requires a tripartite approach: first, senior commanders' conceptualisation of European mortality and sickness must be examined; next, the modes of intellectual reasoning favoured by these senior military officers must be established; finally, these conclusions can be used to provide a reading of black soldiers' place within the military medical environment of the West Indies.

\section{Theories of European Health}

The morbidity and mortality of the 1790s hardly represented a novel feature of West Indian campaigning. The entire plantation economy of the New World was premised on Europeans' apparent susceptibility to the climate, reinforced in a military sphere by notorious disasters like the ill-fated Cartagena expedition of 1740-1742 in which some 10,000 of 14,000 soldiers had died, almost all of them from disease. ${ }^{15}$ The annual toll claimed by the West Indies had provoked a certain 
degree of government introspection as the eighteenth century wore on, but for the most part such losses could be rationalized in a number of ways. For one, the sugar islands were simply too strategically and economically important to be neglected militarily, and in any case the dominant influence of climatic determinist medical thought encouraged the view that, with certain precautions, Europeans could expect to thrive in the tropics, even to the extent of growing blacker over successive generations. ${ }^{16}$ Periodic successes like Grey's sweep of the French islands, a feat previously achieved only over the course of several campaigns in the Seven Years' War, seemed to further demonstrate the capacity of disciplined, motivated European troops to overcome the challenges posed by the Caribbean environment. ${ }^{17}$

The French Revolutionary Wars, however, temporarily changed the face of Caribbean warfare and with it the way in which European mortality was conceptualized. From 1793-1794, and 1798-1815, warfare in the region followed a familiar pattern of amphibious assaults on key coastal objectives. The emancipation of the slaves in the French islands by the Convention of 4 February 1794, however, produced a model of warfare which placed very different demands on the British army in the intervening period. Jacobin agents began to foment rebellion among the black population of the various islands and the indigenous Caribs of St. Vincent and Grenada; far from submitting with the capture of the principal fortifications, the interior of the islands now became the most intractable site of resistance. ${ }^{18}$ Senior commanders were convinced that a fundamental shift had occurred, Vaughan informing the Secretary of State for War, Henry Dundas, that "the war in these Colonies is carried on in a manner totally different to what it was before, even in Sir Charles Grey's time: for the enemy now make it a war of posts, instead of making the Sovereignty of the Island their only object as before. ${ }^{\prime 19}$ The British now faced a mobile enemy, apparently immune to the diseases which afflicted Europeans, motivated by the knowledge that defeat would entail a return to slavery, and ensconced in the mountainous, forested interior of the islands. The novel demands imposed by the prodigious terrain and the new guerrilla warfare made the issue of European adaptation a topic of renewed and important discussion, forcing military commanders to consider afresh their troops' 
capabilities and vulnerabilities. This was compounded by the shift from garrison to campaign structure which hardened the existing division of the year into a "healthy season" from November to April, and a "sickly season" from May to October, since this distinction governed the scope and timing of all offensive operations.

Reacting to Dundas' initial reluctance to approve the WIR, Vaughan wrote an impassioned private letter which neatly encapsulated his core beliefs surrounding the climate, the importance of discipline, and the European capacity for adaptation. The mode of warfare faced by the army was, Vaughan wrote, "unexampled," with the French using the aid not only of the Native white man, but of the negroes who are inured to the Climate, can brave the dangers of it, and can be so easily procured in such great numbers, whilst we are confined to the use of European troops, few in number, rare in discipline, and exposed to the ravages of an unhealthy Climate, with which they are unable to contend, and to which they fall such numerous victims. ${ }^{20}$

The annual campaign cycle entailed relatively regular changes of command, but the eleven commanders-in-chief between 1793 and 1802 demonstrated extraordinary unanimity in directing their focus towards "climate" in the manner exemplified by Vaughan's letter: morbidity and mortality were seen as the product of exposure to the region's dangerous climate, while health was derived from being in some way inured to it. Where Vaughan stressed European vulnerability to the climate's "ravages," other commanders' letters reveal similar rhetorical flourishes in their quest for reinforcements, Sir Ralph Abercromby reflecting on how six of his battalions had been "nearly annihilated." ${ }^{21}$ The latter's temporary replacement, Major-General Charles Graham, meanwhile, described the losses suffered under his command as "distressing to humanity," and informed Dundas that the climate was to be "dreaded, as it is more destructive, than the effects of the most sanguinary Enemy."22 
Contemporary medical theory held that the tropics were dangerous for two reasons. The Caribbean environment was understood to be characterized by rapid putrefaction, a process driven by tropical heat acting on the region's rich vegetation to release the miasmas which proved so fatal to Europeans. This heat was also thought to act on newcomers' bodies, weakening their resistance to these "noxious exhalations" and rendering a period of "seasoning" necessary before good health might be achieved. ${ }^{23}$ The climate was therefore seen to act in both indirect and direct ways on individual bodies but, although the two were evidently not mutually exclusive, by the 1790s the former were regarded as by far the more important. The state of the air had acquired an "almost mythical status" and, in a process characteristic of the eighteenth-century spirit of "improvement," medical practitioners had turned their attention towards methods of curing pathogenic environments which mainly focused around ventilation, lavation, and drainage. The dominance in this period of what has been termed "environmental medicine" is exemplified by the emergence of medical geographies, sometimes expressed cartographically, which attempted to account for the distribution of disease in a scientific manner, and which had already become a key part of the Continental medical police initiatives typical of Foucault's "politics of health." 24

In spite of the prominence of such miasmatic medical thinking, however, senior commanders paid remarkably little attention to the specific environmental factors which might render a location healthy or unhealthy. Their medical thought, by contrast, was based around a far broader climatic aetiology whose focus was the direct impact of heat on the body. Extreme heat had formed part of tropical medical theory since the first European excursions into these regions, but the commanders' discussion of its role moved away from a more seventeenth-century, Hippocratic conceptualisation in which it alone could act as a cause of disease. ${ }^{25}$ Rather, reflecting the parallel rise of nervous theories of disease, the commanders located morbidity at the confluence of heat and fatigue. Over the course of the eighteenth century the biliary theory of fevers was increasingly challenged in the West Indies as humoral ideas were adapted to reflect developments in mechanical and chemical philosophy; rival theories rooted in nervous physiology emerged from William Cullen and his 
acolytes at Edinburgh. ${ }^{26}$ At the heart of these new theories was the concept of nervous debility, which traced disease to depleted energy through the immediate effects of an oppressive atmosphere, or the enervating impact of a tropical climate over a more prolonged period. ${ }^{27}$ Many Edinburgh-educated practitioners pursued military careers, among them Cullen's erstwhile follower John Brown whose stripped-down aetiology reduced health and disease to the degree of stimulation or "excitability" acting on the body; Brown's theory proved understandably popular among military practitioners seeking a means of rapidly diagnosing and treating large numbers of patients. ${ }^{28}$ Indeed, Michael Barfoot has argued that Brunonian ideas were so widely diffused through contemporary medical culture that most medical practitioners had little sense of the origins of the language and sentiments they had absorbed. ${ }^{29}$ Alongside Brown, the influential Robert Jackson's superficially similar theory argued that fevers stemmed from overstimulation of the nervous system; a key factor in this was excessive heat, the nature of the disease being dependent on the degree of stimulation. ${ }^{30}$

It seems, however, that senior commanders too had encountered these ideas. Their writings only rarely adopted the explicitly medical language of "debility," but the commanders-in-chief were clearly confident in their ability to borrow from the concepts of nervous physiology. ${ }^{31}$ Interior warfare had brought about "fatigues of which the Constitutions of European Troops are by no means competent in a West India Climate," indicating that it was not merely the climate itself, but rather its exacerbation of the fatigues which British troops were forced to undergo which caused morbidity. ${ }^{32}$ Dundas' words from 1798 echoed those of Vaughan in his first full appeal to government in 1794: "I beg it may be taken into Consideration, what great Mortality ensues among our Troops from the Fatigues of Service in this Climate." ${ }^{33}$ Although lacking the theoretical grounding to express themselves in a more sophisticated form, commanders apparently had some awareness of the broad outlines of these theories and, for reasons which will be subsequently examined, stressed ideas relating to the direct impact of climate in their own medical thought. This focus on heat and fatigue, two unavoidable elements of West Indian warfare, over the more remediable factors of 
environmental medicine undoubtedly contributed to a sense of pessimism over the future of European troops in the region.

The European capacity for acclimatisation was, however, viewed in terms which were less than absolute than this pessimism might suggest; with proper discipline, commanders reasoned, white troops might still play a valuable role in certain forms of West Indian warfare. As demonstrated in the opening quotation, Vaughan's attention was on the vulnerability of Europeans who were "unaccustomed to the Climate," the implication being that some reversal of this state was possible. The means of achieving this, Vaughan argued, began before the troops had even arrived in the region, noting to Dundas that "in the Age and Discipline of Soldiers consists (most particularly in this Climate) their effective Force" and hence that "Battalions just completed from new Levies, must be very deficient in these Points." ${ }^{34}$ This point was pressed home two months later as Vaughan requested reinforcements "composed of the Troops, which have served on the Continent," since "It is only filling the Hospitals and deceiving yourselves to send out raw, or new-raised Levies." ${ }^{\prime 35}$

Military medical practitioners had long noted the importance of discipline in preventing "disorder," a state which conceptually tied together disease in the individual and indiscipline in camp. ${ }^{36}$ Catherine Kelly has demonstrated that its prominence grew still further in the 1790s following the Army Medical Board's (AMB) decision to restrict physician posts to graduates from a select group of universities. Finding their path to promotion obstructed by a lack of civilian, Oxbridge-based training, many military practitioners began to articulate a distinctly military professional identity which relied heavily on a "militarized" medical practice derived from practical experience rather than inherited theory. ${ }^{37}$ Senior commanders were therefore well within the bounds of military medical orthodoxy in seeing regimental discipline as a way of offsetting the effects of the West Indian climate, but they afforded it a rather more limited role than their medical officers. The implicit assumption underlying their correspondence was that European troops could never be "inured to the Climate" to the extent that they might be able to meet the "unexampled" demands of interior warfare without 
experiencing great mortality. ${ }^{38}$ The use of veteran troops was a means of reducing this mortality, but discipline was only ever treated as a therapy for the effects of the climate, never as a cure. After all, even the troops of the Grey expedition, understood to be the most effective force Britain would be able to gather in the course of the war, had succumbed to sickness "in Consequence of the fatigues they have gone through followed by the present very warm Weather." ${ }^{39}$ Invalids were sent to England, Nova Scotia, or Quebec until the establishment of a hospital at Bermuda in 1795. Lying at some distance from the Windward and Leewards, the island was thought to have a more congenial climate, although the more pressing reasons for its establishment were apparently logistical, it being an easier and cheaper base from which to return troops to their regiments and hence prevent desertion. In any case, it was a decision in which Vaughan showed little interest. ${ }^{40}$ Ultimately, senior commanders still believed that European service in the West Indies would lead to "broken Constitutions" which only a return to cooler regions could remedy. ${ }^{41}$

\section{Personal Experience and Medical Observations}

Senior commanders' intellectual links to military and tropical medicine were, however, more than merely superficial; military officers were embedded within an evolving intellectual environment, active participants in the wider shift towards empirical reasoning in medicine. In the medical setting, this process was bound up in issues of professional authority and driven in a large measure by colonial, principally military and naval, practitioners who sought to assert the primacy of experience and direct observation over what they characterized as the received wisdom of metropolitan physicians; such ideas had come to dominate West Indian practice by the 1790 s, a fact to which the modes of reasoning favoured by senior commanders bear ample testament. ${ }^{42}$

Erica Charters has demonstrated the significance of returns in establishing the centrality of empirical data in the military medical setting. Returns, as Charters points out, offered military medical practitioners information about the morbidity and mortality rates of large groups of anonymized 
individuals on the basis of which they made generalisations about European and non-European bodies. ${ }^{43}$ It should be recognized, however, that in using them to track troop strength and to provide leverage in discussions with Dundas, commanders also unavoidably engaged with theories and assumptions surrounding European morbidity and thus acclimatisation since "every Return and Letter" was a "fresh testimonial" to the deadliness of the West Indian environment. ${ }^{44}$ Commanders were able to map the impact of the climate on their forces, using returns as a tool with which to assess their strength and to calculate the necessary number and distribution of reinforcements. In turn, this led them to draw conclusions about the health of European troops looking forwards as well as backwards, incorporating empirically-founded estimates into their strategic planning. Vaughan, for example, in setting out to the Duke of Portland his plans for the projected reinforcement, proceeded from the assumption that one quarter of his available offensive force would be claimed by sickness before operations had even begun. ${ }^{45}$

Over time, with data from the WIR appearing in returns, such analysis was refined and applied comparatively to discuss differential mortality between European and black troops. Alexander Tulloch's "Statistical Report on Sickness, Invaliding, and Mortality among Troops in the West Indies" (1838) is often treated as the moment at which general impressions of differential racial immunity in the army were finally provided with a systematic statistical basis, but the senior commanders' correspondence demonstrates that this practice had a much longer informal history. ${ }^{46}$ Thomas Trigge, for example, commander-in-chief from 1799 onwards, noted to Dundas as early as 1800 that "the deaths amongst those People [black troops] are comparatively small to what will be found in taking a view of the relative Number of the White and Black Troops, with the deaths that have taken place in each, during any given period." ${ }^{\prime 47}$ This early lay usage of the sort of empirical reasoning which had come to suffuse military medicine allows us to situate the commanders within a shifting intellectual landscape, justifying their claims on the basis of returns and appeals to "past Experience" or "my own knowledge, the result of some observation and experience."48 
"Experience," however, did not merely relate to what these men had observed in returns in the West Indies, but to what they themselves had personally seen, felt, and suffered. After all, senior officers were no less afflicted by the West Indian epidemiological environment than were their men; indeed, in many ways the suffering of the troops simply represented for these men their own experiences writ large. Of Vaughan's immediate predecessors, Thomas Bruce had found that "the Climate...oppressed Him beyond what Europeans usually experience" and had come perilously close to death before returning to Britain where, his constitution said to have been irrevocably damaged, he would die just four years later. ${ }^{49}$ Grey, meanwhile, had witnessed his nephew and all six of his personal servants succumb to disease, subsequently attempting to flee the onset of the unhealthy season in fear as soon as the weather turned "very warm, thick \& Rainy," admitting that he was "not a little worn down by fatigue and the climate." For all the artifice and exaggeration of their letters to Dundas the senior commanders therefore give us few reasons to doubt the sincerity of their fears. If in his public letters to Dundas Grey explained his desire to return home on the somewhat unconvincing grounds that his presence was required to organize and lead a second expedition, privately he complained to his friend Samuel Whitbread of his desperation to leave and never return. ${ }^{50}$

Such personal fears provide crucial context for understanding senior commanders' views of European health. While petitioning Dundas to relieve him of his post in December 1797, Cornelius Cuyler revealed that he had been reluctant to accept the command in the first place, concerned "from having before served near twelve Years in this Country...that I should not be able to stand this Climate for any length of time." Cuyler had been forced home in 1793 by what he described as a severe attack of fever occasioned by his exertions at the capture of Tobago; like Bruce, he had been rendered a tropical invalid, finding that not even the cooler climate of England was enough to restore him to perfect health. ${ }^{51}$ Personal experiences and suffering such as this clearly informed commanders' pessimistic views of the European capacity for acclimatisation, contributing to a sense that service in the region would inevitably end in death or permanent damage to one's health. 
Vaughan wrote to Dundas in May 1795 of his "Fatigue of Body and Mind" and, having experienced much sickness already, expressed his fear that he would suffer again should he not be granted the same indulgence as Grey. ${ }^{52}$ As it happened, his words were almost prophetic: he fell ill again and died the next month. ${ }^{53}$

The "experience" to which senior commanders appealed, and thus their interpretation of the epidemiological environment, was conditioned by the nature of the military command structure. Although all had some experience in the field, few of the commanders from the early years of the wars had any real familiarity with the West Indies prior to their appointment. ${ }^{54}$ None, meanwhile, had faced the type of warfare demanded of British troops in the 1790s, and certainly not in a location as hostile as the Caribbean. This general lack of experience was important because it ensured that their medical opinions on the West Indies, widely understood to be a unique epidemiological environment, were founded largely on their immediate experiences in senior command, a role which often proved more managerial than military. Once offensive operations in the region had fallen victim to financial retrenchments in 1799 , Trigge complained that his position was "more that of a Commissary of Accounts than a military man," but even before this senior commanders were to some extent divorced from the day-to-day realities of military life. ${ }^{55}$ Certainly their role was very different to that of their regimental subordinates who were responsible for ensuring discipline and order in camp and on campaign.

It was unexceptional for senior commanders to be based on a single island, making occasional trips to supervise operations elsewhere but otherwise fulfilling the expectations of polite society, dressing for dinner with governors and acting as the metropole's official representative. ${ }^{56}$ The appointment of Abercromby who, although apparently fit and well for his age, was a 61-year-old with failing sight plainly reflects the role the commander-in-chief was expected to play. ${ }^{57}$ This distance from the rankand-file meant that the direct impact of climate loomed far larger in their experiences than the indirect. When referring to "experience" and "observation," commanders were raising on the one 
hand empirical data from returns, and on the other their own personal experiences of an unfamiliar, alien environment. Taken together, their "experience" thus consisted of feeling the enervating and apparently pathological effect of heat every day, and witnessing its impact on troop numbers.

Concerned fundamentally with absolute troop numbers, a devastating rate of attrition, and demands from all islands for manpower, commanders were drawn to the most obvious manifestations of "climate." Meanwhile, distanced somewhat from the mundane affairs of regimental hygiene, camp siting, and discipline, they were rarely forced to dwell on indirect climatic factors like miasma when it came to decision-making. Consequently, their medical thought was heavily slanted towards the role of heat and fatigue in producing disease, since these were the factors which their personal experience of the West Indies had made most evident.

The significance of personal experience appears still more starkly when the senior commanders' medical views are set alongside those of Sir John Moore, derived from his comprehensive and reflective diary. Famous for his death at Corunna in 1809 but at this point a field officer with the rank of brigadier-general, Moore arrived in the West Indies for the first time with Abercromby's expedition in April 1796 and took part in the assault on St. Lucia in May of the same year. Following the capture of the principal post, the Morne Fortuné, Moore was left with 3000 troops to undertake the suppression of the so-called "brigands" who had fled into the dense interior. ${ }^{58} \mathrm{His}$ perspective on European health and the climate is incredibly valuable to compare with that of his superiors because the individuals dying under his command were not anonymous figures appearing on returns from disparate islands, but men with whom he had contact, languishing in camps which he regularly visited. Put simply, Moore was closer to the men, sleeping, marching, and fighting alongside the common soldier. ${ }^{59}$

Exposed to the limitations of regimental discipline and to the local geography of the island, Moore's medical thinking was far more sensitive to indirect climatic factors and to the significance of proper military order in preserving European health. Indeed, his diary for this period largely reads as an 
extended lament for "that zeal and ardour which I am not too young to have seen," but which he found sorely lacking among his officers. ${ }^{60}$ As is clear from their criticism of recruits, senior commanders did evince disappointment at the quality of the men at their disposal. Moore's criticisms, however, were levelled against the army in general, unfavourably compared to a putative golden age which he felt he had narrowly missed. With occasional exceptions, the troops were "infamous" and the composition of the officer corps "horrid," dictated by money and political interest rather than talent. ${ }^{61}$ No individual was too senior to escape Moore's private censure, Abercromby having allegedly tarnished his reputation by "running away" from St. Lucia before resistance there had been properly suppressed. ${ }^{62}$

Moore's expectations are neatly summed up by his reaction to the loss in January 1797 of the post of Praslin, where the "brigands" had found the captain asleep in the middle of the afternoon, and the men washing in the river or else carousing while on guard duty. Enraged at the negligence of Captain de Marchay, a Frenchman now in the British service, Moore expressed his approval at the man's decision to end his own life, reasoning that any officer with a sense of honour would rather die than survive such a disgrace. ${ }^{63}$ The affecting last letter of Brigadier-General Colin Lindsay who, blaming himself for a series of setbacks, committed suicide at Grenada in 1795 reflects how Moore was by no means unique in being governed by such powerful concepts of military honour. ${ }^{64}$ In St. Lucia he had found a military medical environment in which mortality was high and the basic tenets of discipline and interior economy were being flouted; it was these remediable flaws which therefore became the basis of his medical theory, not the climate. Commanded by officers who either would or could not execute his orders, the regiments in St. Lucia were "literally dying for want of care." ${ }^{65}$

Reflecting in a letter to Abercromby on 2 September 1796, Moore noted that:

The troops, I observe, which have been most active are the most healthy, a proof that the sun is not the cause of the sickness. There are local situations in these islands...which are so 
unhealthy, that perhaps no care and management could altogether counteract the evil effects; but in general the greater part of the sickness proceeds from the want of interior discipline and economy in the regiments. ${ }^{66}$

Moore's interpretation of contemporary medical theory thus demonstrated an entirely different emphasis to that of his superiors. Although he freely acknowledged throughout the diary that European morbidity owed much to the climate, a word he used in an identical fashion to the senior commanders, it remained secondary to his medical thought in much the same way as their views treated discipline and indirect climatic factors. As Moore saw it, modern discipline was not physically demanding enough to inure Europeans to the climate of the West Indies, each day involving perhaps just two hours of parades and firelock exercises which left the troops to pass the rest of their time lounging in poorly ventilated barracks where indolence sapped their bodies of vigour and strength. What Moore termed the "Roman" or "ancient" mode of discipline, however, involved bodily exercises, running, marching, and bathing which together would ensure that the men became accustomed to physical exertion in the enervating heat. Moore regarded himself as the exemplar of the good effects of such a regimen, his own impressive demonstrations of stamina testifying to its benefits. $^{67}$

These medical views bear a striking resemblance to those of Robert Jackson, for whom discipline was understood to have physiological effects. Evidently, Jackson provided far more theoretical justification for his arguments, noting, for example, how arrival in the tropics could induce a plethoric state of the body in undisciplined troops which, when combined with the exertion involved in military operations, hastened the appearance of the remitting fever. ${ }^{68}$ Like Moore, however, Jackson felt that Europeans were healthiest when active and could be inured to the West Indian climate, even to the point of being equally capable of sustaining fatigue as "the African, or the native of the islands." ${ }^{\prime 69}$ The means of achieving this again involved a mixture of internal economy through 
temperance, military discipline, and regular exercise in the form of running, swimming, and wrestling which would "harden the body" and "increase the power of the limbs." "70

The critical point is thus that Moore's experience of warfare in the West Indies was vastly different to that of the senior commanders. Closer to the rank-and-file, Moore's conception of the limitations of his force were not merely quantitative, but also more clearly qualitative. Hence, his eye was drawn not only to the direct effects of the climate, but to other areas of contemporary military medical theory, namely to the discipline and interior economy which the regiments evidently lacked. Championing his own "experience" of the West Indies as justification, Moore advocated sending a body of 800-1000 black troops to scour the woods since the British were "incapable" of acting in the interior. His evident faith in acclimatisation, however, shows that he saw this not as some intrinsic defect, but as a reflection of their lack of discipline and poor leadership. ${ }^{71}$ Furthermore, able to focus his attention solely on operations in St. Lucia, Moore apparently had a keener sense of medical geography than his superiors, noting the exceptional morbidity at the Morne Fortuné on several occasions. ${ }^{72}$ On this point, it is notable that the commander-in-chief to first alert Dundas to the threat posed by the swamp next to the camp at Prince Rupert's in Dominica was Cuyler, a man with twelve years of experience as a field officer in the region prior to his appointment. ${ }^{73}$ Senior commanders were not ignorant of medical geography, but officers' personal experiences in the West Indies clearly shaped their perspective on medical theory, and hence on European troops. As a result, there arose the seemingly paradoxical situation in which the closer an officer was (or had been) to the destructive effects of disease on the rank-and-file, the greater was his faith in the potential for European troops in the Caribbean. Reference to eighteenth-century military medical theory, however, shows this situation to have been quite explicable: proximity to the day-to-day realities of service in the region seemingly drew these men's attention to the many medical factors which were neglected and which, properly attended to, could thus act as means of offsetting what all recognized as a dangerous climate. The vast differences in experience between senior 
commanders and their field officers ensured that they generally held medical views whose core features were similar, but which were subject to very different degrees of emphasis.

That these commanders felt comfortable expressing medical views was a reflection in part of the hierarchical nature of the military command structure. Even prior to their arrival in the West Indies, commanders saw themselves as above their medical staff, the AMB complaining that Grey "did not once consult or take the advice of any medical officer, not even of the Director General of his own hospital." ${ }^{74}$ Abercromby, meanwhile, was governed by the belief that "A General who means to succeed, must follow his own ideas, command his army himself, and choose his own assistants." 75 This last proved a particular source of friction between the commanders and the AMB, representing a conflict over which group should control medical appointments. The AMB repeatedly aired its grievances to the Secretary at War, William Windham, arguing that "the Appointment of Medical Persons must turn in propriety on Three points; that of Length of Service, Ability or an overruling necessity." Commanders-in-chief, they stated, could assess the first and third qualifications as well as anyone, but were not competent to assess the second; it was for this reason that the king had delegated this responsibility to others. ${ }^{76}$ Successive commanders-in-chief, however, followed Grey's lead in appointing "improper" practitioners, Vaughan violating the AMB's policy of maintaining the distinction between surgery and physic, and Abercromby dismissing the AMB-appointed inspector general in favour of his own candidate, Thomas Young. ${ }^{77}$ The AMB sought to make the assessment and appointment of medical practitioners its sole prerogative, but commanders were equally determined to resist this encroachment on their authority. That they apparently claimed the right to pronounce on medical matters from before their departure for the Caribbean indicates that they saw this as a right underpinned at least in part by traditional ideas of military hierarchy.

As we have seen, however, commanders derived their sense of entitlement from intellectual currents which were broader than the purely military. Far from riding roughshod over it as the AMB's complaints might suggest, the officers engaged with medical authority on its own terms; their 
assumption was not merely that they had the right, but also the competence to voice medical opinions. Kelly has identified how the significance of discipline in the military medical setting drove commanders' faith in their own medical expertise, a fact of which Moore is emblematic. ${ }^{78}$ However, there was more at stake than just discipline. The frequent recourse to "observation" and "experience" saw these men employ tropes more familiar in a medical sphere to justify their medical opinions; in doing so, they turned against the military culture in which they had forged their careers and in which authority was still largely textual and centred on the examples of past generations.

Driven from mid-century by the growing consensus that soldiering was a profession, British officers of their generation had turned to Continental (especially French) works on the art of war whose content was shaped more by Enlightenment intellectual trends than European warfare. ${ }^{79}$ War was, according to these works, a science and therefore subject to universal principles which had governed victory and defeat since the time of the ancients. Their elucidation, figures like the Marquis de Puységur argued, involved the systematic analysis of historical case studies, and had thus actually been obstructed by a reliance on personal experience. ${ }^{80}$ Works by Saxe, Vauban, and Puységur thus took their place alongside Caesar's Commentaries, Polybius' Histories, and various biographies of Marlborough in the texts most popular among senior army officers in the age of the American Revolution. $^{81}$

The modes of reasoning and claiming legitimacy used by Vaughan, Abercromby and others did not therefore emerge from within the military itself but rather, it appears, from their interaction with practitioners engaged in parallel developments in the medical sphere. It seems that the West Indies of the 1790s was home to a shared empirical culture which used the perceived uniqueness of the region's military and medical environment to react against a faith in received wisdom, placing authority instead in personal experience. If little is known about Young's personal opinions, his faith in the capacity of surgeons to act medically, his preference for regimental over garrison hospitals, and his fractious relationship with the AMB could be said to bear the imprint of Jackson, and at the 
very least to point to him as an ardent believer in the value of experience. ${ }^{82}$ His close relationship with Abercromby makes the exchange of ideas between the two seem almost inevitable, Young presumably meeting his future patron in Holland in 1793 or 1794, then following him to the West Indies in 1795, where he displaced as inspector general his successor as garrison surgeon of Grenada, John Macdonald, and then to Egypt in 1801 where Abercromby had him installed as head of the medical department at the expense of the Cambridge-educated physician, James Franck. ${ }^{83}$

For his part, Abercromby also benefited from the relationship. If privileging "observation" and "experience" aided colonial practitioners in asserting their professional qualifications in the face of metropolitan rivals, it also made the boundary between lay and medical increasingly porous. Commanders may have lacked a detailed theoretical grounding, but could legitimize their opinions by calling upon the sorts of "observation" and practical military "experience" employed by medical practitioners and used to defend the distinctiveness of military medical practice in the face of the AMB's recruitment of civilian physicians ${ }^{84}$ The deeply hierarchical setting of the military further eroded medical practitioners' claims to be the sole guardians of medical knowledge, giving commanders a strong sense of their right to pronounce on medical matters. Thus, just as military medicine was, as Kelly points out, becoming "militarized," the army in the Windward and Leeward Islands was to some extent simultaneously becoming "medicalized."

These intellectual developments enabled senior commanders to successfully expand their range of influence over policy-making. In November 1798, for example, with the financial cuts which accompanied the end of offensive operations in the region, the Commissioners of Victualling investigated whether the expensive Fayal wine provided for the troops in the West Indies might be replaced at least in part by rum without damaging their health. In doing so, they turned to an individual whose expertise in such medical affairs was guaranteed by his "particular Knowledge of the Climate \& other local Circumstances;" that individual was not a member of the AMB, nor indeed a medical practitioner at all, but rather Abercromby, the former commander-in-chief. ${ }^{85}$ That Dundas 
apparently pursued the establishment of the WIR on the back of the medical opinions given by these commanders alone suggests that the government was of a similar mind.

\section{Evaluating the Black Corps}

The utility of black troops was viewed as inseparable from the vulnerability of their white counterparts, disease resistance acting as the principal point of comparison. In contrast to the inherent unsuitability and narrow bounds of acclimatisation attributed to white troops, black soldiers were seen to be intrinsically well-suited to life in a tropical climate. As noted earlier, the shift to interior warfare was central to the introduction of black troops because it placed greater emphasis on the ideas of heat and fatigue which dominated senior commanders' medical thought. In doing so, it made different traits desirable, elevating physical over purely military capabilities; specifically, it was often said that each black soldier could stand for three Europeans when it came to fighting in the region. ${ }^{86}$ In an early petition to Dundas, Vaughan therefore sought to convey the fundamental change wrought by revolutionary France's use of black soldiers; Britain was, he wrote, no longer competing on "equal Terms," for operations in the region now demanded a type of warfare which "our Troops are not formed to execute." The only solution to a problem which was fundamentally physical in nature was "opposing Blacks to Blacks," a tacit acceptance that military ability alone was no longer sufficient to ensure success. ${ }^{87}$

Black troops were seen as "formed" for this sort of warfare not for any absolute physical qualities like strength, but rather for their ability to undergo the necessary extremes of fatigue without succumbing to disease. The contracts drawn up with slave traders for recruits illustrate that the qualities the army sought in its slaves were unrelated to raw physical characteristics. Minimum height requirements were imposed of five feet six inches for creoles, five feet five inches for adult "New Negroes," which is to say slaves born in Africa and newly arrived in the Caribbean, and five feet three inches for boys who looked likely to grow further. ${ }^{88}$ These minimum height requirements 
were marginally above the average height for creole and African-born slaves at the time, but were similar to those demanded of British infantrymen, who had to be at least five feet six inches tall to be accepted into a line regiment. ${ }^{89}$

Instead, commanders sought a physical advantage which was constitutional in nature, an intrinsic quality restricted to people of African descent. Senior commanders understood their black troops to be "People of the Climate," unaffected by the vagaries of the seasons and able to endure even the most extreme of tropical conditions. ${ }^{90}$ Within this broad view, however, there remained room for ideas of acclimatisation which distinguished between West Indian and African-born slaves. The initial stages of purchasing recruits for the WIR specified the provision of "seasoned Negroes" and, once army policy had become the purchase of African-born slaves, Trigge noted that all those newly imported to the Caribbean were equally subject with Europeans to a period of seasoning in which they rarely escaped a bout of illness; this was already a well-established opinion within the wider slave trade.${ }^{91}$ The difference between Africans and Europeans, however, was that this seasoning process was seen to effect a far greater level of disease resistance in the former. If West Indian-born whites were seen to possess certain advantages over Europeans, the idea of using the militia as a force in the interior was never seriously entertained. It was only black and, crucially, mulatto soldiers who were considered appropriate for such a challenging role, implying a belief in some sort of intrinsic physical advantage which was more racial than environmental; not even several generations of residence in the region could produce the level of climatic resistance effected by miscegenation. Commanders therefore adhered to a qualified climatic determinism in their belief that white West Indians enjoyed better health than Europeans, but in another sense their ideas were closer to a more pessimistic nineteenth-century view of distinct races between which no environmental influence could mediate. ${ }^{92}$ This placed them at odds with mainstream medical orthodoxy, which still largely rejected the idea that differential resistance was a product of innate dispositions; the military physician John Hunter, for example, believed that Europeans could become acclimatized within a single lifetime. ${ }^{93}$ 
However, the other side of this comparative approach was the general belief that black men made inferior soldiers, being less amenable to discipline and military life than their white counterparts. The loss of St. Lucia and Guadeloupe had demanded a new, albeit grudging, respect for France's black soldiers, Abercromby's general orders read aloud to the troops evincing a caution entirely lacking in Grey's from January $1794 .{ }^{94}$ There is, however, little suggestion in either the public or private correspondence that British self-confidence had been noticeably damaged in this regard.$^{95}$ After all, British self-image dictated that black troops could not be seen as both physically superior and militarily equal to European soldiers; the denigration of the slaves' military potential was a direct reflection of the anxiety Europeans felt at their own physical vulnerability in the region. Moreover, although a fair proportion of the black troops the British encountered probably had some military experience in Africa, it is unlikely that they exhibited the sorts of qualities of order and structure over which contemporary military thought obsessed. ${ }^{96}$ Senior commanders therefore believed that such troops would not be fit for service unless led by and fighting alongside white officers and regulars. Dundas exemplified this attitude, expressing his concern to Grey that the French forces in Guadeloupe had been so reduced as to be "totally incapable of even restraining in any degree the ravages which those people [the black soldiers] may be disposed to commit." ${ }^{\prime 97}$ Military efficiency in the Caribbean was therefore understood to rely on combining these complementary forces so as to create a body of men with the tactical and technical precision of the European, and the physical abilities of the African. Chastising Alexander Lindsay, the $6^{\text {th }}$ Earl of Balcarres and governor of Jamaica, for his uncooperative behaviour, the Duke of Portland wrote that his request for a solely European force would:

militate against the very principle of the Plan itself, which by mixing Troops composed of Negroes and Men of Colour with our European Forces, is intended to give strength and efficacy to both, not merely in proportion to their numbers respectively but by a judicious 
combination of their Force which it is conceived when so composed must be infinitely superior to the same number of Europeans acting alone as heretofore. ${ }^{98}$

Black troops were never simply intended as a manpower policy, a like-for-like replacement for the European troops who succumbed to disease. Rather, they were raised to be deployed alongside white soldiers in situations where their physical advantages could best be exploited. The racial division of military labour was unofficial, but it was certainly well-understood and provided with the occasional explicit expression. Vaughan, the first driving force behind the WIR, was unambiguous in his assessment, informing Dundas that the Black Carolina Corps had recently been sent to St. Lucia to "drive them [the "brigands"] from their Retreat on a Mountain; which being judged to be a Service of more Fatigue than Danger, was a proper Enterprise on which to employ the Blacks, and to save our own Soldiers." It was only after this approach had met with a spirited but costly defeat that the British regulars had been drafted in and, supported by light artillery, had put the enemy to flight. ${ }^{99}$

Read in this light, many other facets of military life in the West Indies become more explicable. Seen to be possessed of very different characteristics, black and white troops were subject to rather different expectations from senior commanders. The discipline demanded of black troops in the British service was of a different nature to that expected of European regulars, representing a desirable but not essential trait in their health and military effectiveness. Moore wrote of his optimism at the potential shown by the black corps under his command before noting that "Even as they are at present they are for the West Indies invaluable." Put simply, even before "proper attention" had been paid to instil in them the discipline Moore so valued, black soldiers were a priceless resource for operations in the region. ${ }^{100}$ This comment also hints at a wider understanding that discipline was not a factor in the health of black troops, exempting them from a major building block of military medical theory and suggesting again that they were regarded as different to their 
white counterparts in an intractable, biological way. Their military defects were outweighed by the simple, inherent ability to outlive their European counterparts.

\section{Pioneering Pioneers?}

This perception of black troops' value severely circumscribed their role during this period, trapping the WIR within a self-fulfilling prophecy. In terms of the disciplining and training of the black corps, the occasional references made in the correspondence suggest that the men received only rudimentary instruction based around a cursory consideration of the type of operations for which they were destined. Despite the nature of their intended role, black troops on the British establishment were equipped as line regiments, dressed in traditional red coats and wielding cumbersome, unreliable muskets; by contrast, the light infantry of the $60^{\text {th }}$ Regiment were fitted out in a manner understood to be much more appropriate for "Bush fighting," clad in green and armed with rifles. ${ }^{101}$ In fact, it was not until 1801 that it was decided to give the WIR special light infantry training, well after the end of the principal disturbances in the islands, as if the technical aspects of military activity in the interior were until this point a mere afterthought to the knowledge that black troops were at least physically well-suited to such a role. ${ }^{102}$

Such training in basic drill and manoeuvres as the black corps did receive was found to be a process which demanded constant attention, enormous patience, and time which the British simply did not possess. Describing the drilling of the South American Rangers, whom he light-heartedly termed the "awkward squad," the physician George Pinckard noted the violence meted out by the black noncommissioned officers in their haste to train the rank-and-file, a task whose difficulty was not lost on him. Although an open supporter of the policy, Pinckard sought to evoke the absurdity of the scene before him, describing a tableau of irascible, self-important officers and men who, removed from the imposed ignorance and toil of slavery, were little better than oxen taken from the plough. It seemed, Pinckard wrote wryly, "nearly as practicable to train a party of mules to carry arms."103 
The language barrier created by the policy of purchasing only New Negroes exacerbated these difficulties. Buckley has marked out Lieutenant-General Henry Bowyer as a key figure of opposition to the WIR among the senior commanders, but hostility is far less apparent in Bowyer's letters than a ready acknowledgement of the difficulties aroused by the linguistic and cultural divide. ${ }^{104} \mathrm{New}$ recruits were welcomed into the British army by having an English name suspended on a string around their neck, to which they were taught to respond along with the various words of command. ${ }^{105}$ Bowyer, however, raised concerns that this limited European vocabulary, combined with the disruptive effects of certain animistic beliefs such as their fear of "Jambee," made their disciplining at best time-consuming, and at worst potentially impossible. His recommendation to dissolve the WIR and distribute the men among European line regiments was thus not an expression of opposition, but rather the logical extension of the policy outlined by the Duke of Portland; combining the forces would be the swiftest means of deriving value from men who in their present state could not "in any time or in any Situation be much depended upon." 106

Valued for their physical rather than military aptitude, and impelled in part by the urgency of wartime, the training afforded to these recruits was thus apparently insufficient and ill-adapted to the role for which they were mainly envisaged. The result was a vicious circle of unskilled military labour very similar to that which had prevailed in India in the 1750 s and 1760 s when the East India Company first began to employ sepoys in large numbers. The sepoys were not integrated into European regiments and, as with the WIR, were organized separately on returns. Lacking an understanding of European firearms and drill, they were deployed in fatigue roles which reinforced existing beliefs about their physical stamina and unskilled labouring status. ${ }^{107}$ As Channa Wickremesekera has argued, over time these views hardened into ideas of superiority and inferiority which held that sepoys were unfit for the most challenging military duties, and were in need of constant white supervision. These in turn laid the foundation for the racist ideology of the nineteenth century. ${ }^{108}$ For the WIR, their physical abilities were seen to suit them to a particular role in the interior, one for which their inherent disease resistance was more important than any sort of 
military training. When this lack of training was exposed, however, it was taken as further justification of the very beliefs which, in comparing black and white troops, had caused the situation in the first place. When Brigadier-General William Myers complained that the St. Vincent Rangers would "not move without regulars as they say, to support them, that is, to lead them into fire and cover them coming out of it," he was unwittingly bemoaning a problem of the army's own making. ${ }^{109}$

For all the professions both in the correspondence and the historiography that the WIR were to be in all regards equal to European infantrymen, the wider evidence therefore actually suggests that the army's black troops were treated as something rather less than regular soldiers. In fact, the introduction of black soldiers should be seen as representing an extension of slaves' long-established role as pioneers in the West Indies. Far from being the sort of revolutionary pioneers envisaged by Buckley, the WIR began their existence closer to pioneers in the more traditional sense of the word. ${ }^{110}$ Slaves had been deployed in military labouring roles in the West Indies since the beginning of the eighteenth century, a practice directed by the same logic which drove the WIR and indeed the institution of slavery itself, namely the perceived inability of Europeans to sustain fatigue in the torrid heat of the tropics. The boundaries between the black corps' principal military role, namely duties "of more Fatigue than Danger" as Vaughan put it, and these traditional labouring duties were fluid, and left the WIR to occupy an uneasy middle ground between pioneer and regular soldier. Indeed, prior to their being purchased by the government, the men of privately-raised corps such as Druault's and O'Meara's were hired from their owners "upon Pioneer allowance," an administrative oddity perhaps, but one which reinforces the sense that black troops' identity as a purely military force was ambiguous. ${ }^{111}$ Even Malcolm's Rangers, one of the most prized black corps on the British establishment, were used heavily as pioneers at the reduction of St. Lucia in $1796 .{ }^{112}$ Over the course of the 1790 s and into the early nineteenth century, the WIR drifted more towards the labour side of this continuum as it became less and less economical to hire pioneers as a separate body; indeed, the mutiny of the $8^{\text {th }}$ WIR at Dominica in 1802 was provoked by fears among the men that their recent labour work presaged an end to their military status and a return to field slavery. ${ }^{113}$ There 
were, moreover, fairly numerous suggestions either to disband the regiments and assign the men to pioneer roles, or simply to exploit their labour potential to a greater extent. ${ }^{114}$

Looking forward, the rationale behind the WIR remained the same even after operations in the region began to wind down and a more familiar garrison structure re-emerged. The idea that the West Indian garrison should be solely comprised of black troops was never seriously considered; in fact, it was formally decided in 1799 to limit the proportion of black to white troops in each island to one third. This decision can clearly be traced only in part to the vocal opposition of the colonial legislatures and the complex racial politics of West Indian slave societies identified by Buckley. ${ }^{115}$ In part, the decision was clearly also a matter of perceived military efficiency, of providing a force thought able to take on the military as well as physical demands of warfare in the Caribbean. White mortality remained a serious problem, and the threat of encountering an all-black force was still very real prior to Napoleon's restoration of slavery. The black constitutional advantage thus remained crucial, although the army had come to realize that they were actually more liable to sickness than was generally thought, a result mostly of New Negroes' need for "seasoning." ${ }^{116}$ Nonetheless, reacting in 1800 to a set of returns which showed twice the sickness in the WIR as in the European regiments, Dundas anxiously wrote to Trigge to demand an explanation for a situation he could "scarcely imagine" was accurate. "One of the principal inducements for the Formation of these Corps," Dundas wrote, "was the conviction that they were more competent to all duties of exertion and fatigue, and less liable to sickness and the debilitating effects of a tropical Climate than European Troops." ${ }^{117}$ As it turned out, the new recruits to the WIR were suffering from their recent inoculation against smallpox, but Dundas' panicked letter is telling: what was the use of the WIR if they could not outlive their European counterparts?

\section{Conclusion}


In his 1788 Observations on the Diseases of the Army in Jamaica, John Hunter recommended the establishment of black corps for service in the West Indies, noting that more value could be derived from slaves as soldiers than as pioneers. ${ }^{118}$ Notable though such expressions were, the ultimate creation of the WIR was reliant on a different medical rationale to that put forth by Hunter or indeed any other prominent medical officer of the period. The story of the WIR was one of senior military officers participating in and helping to advance the empirical culture of military medicine, making decisions on the basis of views which drew upon, but were ultimately different to, those of their most celebrated medical counterparts.

Senior commanders like Vaughan drove the formation of the WIR in the belief that European troops would never be suitable to undergo the fatigues demanded by warfare in the mountainous interior of the West Indian islands, an opinion conditioned by their unique position in relation to the rankand-file. The WIR's military role was thus inextricably linked to their medical underpinning, as a result of which they were destined to remain glorified pioneers more than regular British soldiers. This uncertain military status would find echoes in the later reluctance to deploy the WIR and the volunteer British West Indies Regiment in combat roles during the First World War.

More broadly, recognising military officers as mobilizers and shapers of medical thought encourages us to reconsider the parameters of traditional intellectual histories. If senior commanders in the West Indies seemingly remained little interested in the intricacies of medical policy, this did not prevent them from holding medical opinions which shaped the decisions they made, suggesting that work remains to be done on the nature of military medical authority, and the extent to which patronage networks, like that headed by Abercromby and Young, could also be intellectual networks. Military historians must be more aware of this tendency, while medical historians should not assume that the famous medical texts of the age necessarily represent a mirror of actual practice, or an accurate guide to policies. After all, the commanders shared the same empirical culture as their medical counterparts, one which had strengthened practitioners' positions at home 
but left them vulnerable to challenges from laymen who had also "observed" the West Indian epidemiological environment; the professionalization of military medicine entailed sacrifice as well as gain.

${ }^{1}$ The National Archives, UK (TNA), WO 1/31, Vaughan to Portland, 22 December 1794.

${ }^{2}$ TNA, WO 1/31, State of the Garrisons in the Charibbee Islands on the $1^{\text {st }}$ November 1794.

${ }^{3} \mathrm{M}$. Duffy, Soldiers, Sugar, and Seapower: The British Expeditions to the West Indies and the War against Revolutionary France (Oxford: Clarendon Press, 1987), 105. A useful overview of the revolutionary period in the Caribbean is available in D. Gaspar and D. Geggus (eds.), A Turbulent Time: The French Revolution and the Greater Caribbean (Bloomington: Indiana University Press, 1997). On the French political and military context, see L. Dubois, A Colony of Citizens: Revolution \& Slave Emancipation in the French Caribbean, 1787-1804 (Chapel Hill: University of North Carolina Press, 2004), 222-48; and F. Régent, "Revolution in France, Revolutions in the Caribbean," in The Routledge Companion to the French Revolution in World History, ed. A. Forrest and M. Middell (New York: Routledge, 2015). For the French military medical background, see L. Brockliss and C. Jones, The Medical World of Early Modern France (Oxford: Clarendon Press, 1997), 689-700. ${ }^{4}$ The raising of black corps was a complicated, piecemeal process in which a number of locally-raised ranger corps were at various times drafted into, or else formed the basis of, British regiments which came to be known as the West India Regiments (WIR). To avoid confusion, 'WIR' will be used as an umbrella term for all black corps under British control, whether or not they had already been placed on the British establishment or denoted as WIR. Individual corps will be named where specificity is required.

${ }^{5}$ R. Chartrand, “Black Corps in the British West Indies, 1793-1815," J. Soc. Army Hist. Res. 76 (1998), 248; R. Buckley, Slaves in Red Coats: The British West India Regiments, 1795-1815 (New Haven: Yale University Press, 1979), 55-56.

${ }^{6}$ For the pre-revolutionary period, see P. Kopperman, "The British Army in North America and the West Indies, 1755-83: A Medical Perspective," in British Military and Naval Medicine, 1600-1830, ed. G. Hudson (Amsterdam: Rodopi, 2007); J. D. Alsop, “Warfare and the Creation of British Imperial Medicine, 1600-1800," in British Military and Naval Medicine, 1600-1830, ed. G. Hudson (Amsterdam: Rodopi, 2007); and M. Harrison, Medicine in an Age of Commerce and Empire (Oxford: Oxford University Press, 2010). 
7 J.R. McNeill, Mosquito Empires: Ecology and War in the Greater Caribbean, 1620-1914 (Cambridge:

Cambridge University Press, 2010); K. Kiple, The Caribbean Slave: A Biological History (Cambridge: Cambridge University Press, 1984).

8 J. Fortescue, A History of the British Army, vol. 4 (London: Macmillan, 1906), 385.

${ }^{9}$ See, for example, McNeill, Mosquito Empires, 63; D. Geggus, Slavery, War, and Revolution: The British Occupation of Saint Domingue, 1793-1798 (Oxford: Clarendon Press, 1982), 370-72.

${ }^{10}$ N. Cantlie, A History of the Army Medical Department, vol. 1 (Edinburgh: Churchill Livingstone, 1974); R.L. Blanco, “The Development of British Military Medicine, 1793-1814,” Mil. Aff. 38:1 (1974), 4-10.

${ }^{11}$ C. Kelly, War and the Militarization of British Army Medicine, 1793-1830 (London: Pickering \& Chatto, 2011);

M. Ackroyd, L. Brockliss, M. Moss, K. Retford, and J. Stevenson, Advancing with the Army: Medicine, the Professions, and Social Mobility in the British Isles, 1790-1850 (Oxford: Oxford University Press, 2006).

12 Harrison, Medicine, 65.

${ }^{13}$ W. Churchill, "Efficient, Efficacious and Humane Responses to Non-European Bodies in British Military Medicine, 1780-1815," J. Imp. Comm. Hist. 40:2 (2012), 137-58.

${ }^{14}$ Duffy, Soldiers, 362.

${ }^{15}$ McNeill, Mosquito Empires, 167.

${ }^{16}$ Harrison, Medicine, 83.

${ }^{17}$ Duffy, Soldiers, 95-97.

${ }^{18}$ Buckley, Slaves, 82.

19 TNA, WO 1/83, Vaughan to Dundas, 18 April 1795.

${ }^{20}$ TNA, WO 1/83, Vaughan to Dundas, 18 April 1795.

${ }^{21}$ TNA, WO 1/86, Abercromby to Dundas, 16 January 1797.

22 TNA, WO 1/86, Graham to Dundas, 16 October 1796.

${ }^{23}$ Harrison, Medicine, 64.

${ }^{24}$ A. Bewell, Romanticism and Colonial Disease (Baltimore: Johns Hopkins University Press, 1999), 29-33; M. Foucault, "The Politics of Health in the Eighteenth Century," in Power/Knowledge: Selected Interviews and Other Writings, 1972-1977, ed. C. Gordon (Brighton: Harvester, 1980), 175; J. Riley, The Eighteenth-Century Campaign to Avoid Disease (Basingstoke: Macmillan, 1987).

${ }^{25}$ Harrison, Medicine, 44. 
${ }^{26}$ Ibid., 113.

27 Ibid., 85.

${ }^{28}$ C. Lawrence, "Cullen, Brown, and the Poverty of Essentialism," in Brunonianism in Britain and Europe, ed. W. Bynum and R. Porter (Medical History, Supplement 8, London, 1988), 6.

${ }^{29}$ M. Barfoot, "Brunonianism Under the Bed: An Alternative to University Medicine in Edinburgh in the 1780s," in Brunonianism, ed. Bynum and Porter, 25.

${ }^{30}$ Harrison, Medicine, 106.

${ }^{31}$ TNA, WO 1/85, Hunter to Leigh, 19 January 1796.

32 TNA, WO 1/86, Dundas to Bowyer, 22 August 1798.

33 TNA, WO 1/83, Vaughan to Dundas, 25 December 1794.

${ }^{34}$ TNA, WO 1/83, Vaughan to Dundas, 25 February 1795.

${ }^{35}$ TNA, WO 1/83, Vaughan to Dundas, 25 April 1795.

${ }^{36}$ E. Charters, Disease, War, and the Imperial State (Chicago: The University of Chicago Press, 2014), 92-93.

${ }^{37}$ Kelly, War, 14-17.

38 TNA, WO 1/83, Vaughan to Dundas, 18 April 1795.

${ }^{39}$ Duffy, Soldiers, 63; TNA, CO 318/13, Grey to Dundas, 6 May 1794.

${ }^{40}$ TNA, CO 318/13, Dundas to Grey, 16 July 1794; TNA, WO 1/83, Medical Staff to Vaughan, 23 March 1795; TNA, WO 1/83, Dundas to Vaughan, 4 June 1795, no.17.

${ }^{41}$ TNA, WO 1/86, Graham to Dundas, 15 November 1796.

42 Harrison, Medicine, 256; ibid., 65.

${ }^{43}$ E. Charters, "Making bodies modern: race, medicine and the colonial soldier in the mid-eighteenth century," Patterns of Prejudice 46 (2012), 215.

${ }^{44}$ TNA, WO 1/86, Graham to Dundas, 15 November 1796.

45 TNA, WO 1/31, Vaughan to Portland, 24 November 1794.

${ }^{46}$ See, for example, P. Curtin, Death by Migration: Europe's Encounter with the Tropical World in the Nineteenth Century (Cambridge: Cambridge University Press, 1989), 3; and Kiple, Caribbean Slave, 169.

47 TNA, WO 1/90, Trigge to Dundas, 20 November 1800.

${ }^{48}$ TNA, WO 1/31, Vaughan to Portland, 24 November 1794; TNA, WO 1/90, Trigge to Dundas, 20 November 1800. 
49 TNA, CO 318/12, Poole to Nepean, 20 October 1793; R. Thorne, The History of Parliament: The House of Commons 1790-1820, vol.3 (London: Secker \& Warburg for the History of Parliament Trust, 1986), 290.

${ }^{50}$ TNA, CO 318/13, Grey to Dundas, 12 April 1794; Duffy, Soldiers, 129.

${ }^{51}$ TNA, WO 1/86, Cuyler to Dundas, 22 December 1797.

52 TNA, WO 1/83, Vaughan to Dundas, 12 May 1795, no.27.

53 TNA, CO 318/14, Irving to Portland, 1 July 1795.

${ }^{54}$ R. Cornish, "Grey, Charles, first Earl Grey (1729-1807)," in Oxford Dictionary of National Biography, ed. H. Matthew and B. Harrison (Oxford: Oxford University Press, 2004); P. Thomas, "Vaughan, Sir John (c.17311795)", in Matthew and Harrison, Dictionary; Duffy, Soldiers, 163.

${ }^{55}$ Duffy, Soldiers, 312.

${ }^{56}$ TNA, WO 1/88, Johnstone to Dundas, 12 July 1798.

57 J. Maurice (ed.), The Diary of Sir John Moore (London, 1904), 208.

${ }^{58}$ Duffy, Soldiers, 112.

${ }^{59}$ Maurice, Diary, 235-38.

60 Ibid., 240.

61 Ibid., 232; ibid., 240.

62 Ibid., 221.

63 Ibid., 246-47.

${ }^{64}$ TNA, WO 1/31, Lindsay to Vaughan, 21-2 March 1795.

65 Maurice, Diary, 235.

66 Ibid., 239.

${ }^{67}$ Ibid.; ibid., 249.

${ }^{68}$ R. Jackson, A Treatise on the Fevers of Jamaica (London: printed for J. Murray, 1791), 394-95.

${ }^{69}$ Jackson, Treatise, 403-4. This brings into doubt Buckley's claim that Jackson's opinions on black resistance to yellow fever influenced the government's decision to raise the WIR: see Slaves, 7-8.

70 Jackson, Treatise, 408-9.

${ }^{71}$ Maurice, Diary, 231.

72 See, for example, Maurice, Diary, 231 and 239; TNA, WO 1/85, Moore to Graham, 19 August 1796.

73 TNA, WO 1/86, Cuyler to Dundas, 4 October 1797. 
${ }^{74}$ Duffy, Soldiers, 350.

${ }^{75}$ Duffy, Soldiers, 164.

${ }^{76}$ WO 7/102, AMB to Windham, 23 March 1795.

${ }^{77}$ WO 7/102, AMB to Windham, 8 July 1795; WO 7/105, AMB to Windham, 3 June 1797.

${ }^{78}$ Kelly, War, 24.

${ }^{79}$ I. Gruber, Books and the British Army in the Age of the American Revolution (Chapel Hill: University of North Carolina Press, 2010), 14-18.

${ }^{80}$ A. Gat, A History of Military Thought: From the Enlightenment to the Cold War (Oxford: Oxford University Press, 2001), 36.

${ }^{81}$ Gruber, Books, 280-81.

${ }^{82}$ T. Keate, Observations on the Fifth Report of the Commissioners of Military Enquiry (London: Printed for J. Hatchard, 1808), 37; TNA, WO 1/86, Young to Cuyler, 30 September 1797, Kelly, War, 60.

${ }^{83}$ If one considers, for example, James McGrigor's medical discussions with Wellington and others: see Kelly, War, 105-10. For Young's career, see W. Johnston and H. Howell (eds.), Roll of Commissioned Officers in the Medical Service of the British Army...1727-1898 (Aberdeen: The University Press, 1917), 56; The Scots Magazine, vol. 55 (Edinburgh: Printed by Murray and Cochrane, 1793), 259; Kelly, War, 88.

${ }^{84}$ Kelly, War, 15-17.

${ }^{85}$ TNA, WO 1/86, Unknown to Abercromby, 26 November 1798.

${ }^{86}$ TNA, WO 1/31, Vaughan to Portland, 22 December 1794; TNA, WO 1/83, Nicolls to Vaughan, 11 May 1795.

${ }^{87}$ TNA, WO 1/83, Vaughan to Dundas, 25 December 1794.

${ }^{88}$ TNA, WO 1/86, Bontein Contract; TNA, WO 1/86, Chollet to Cuyler, 21 March 1798; TNA, WO 1/86, Duncan Campbell Contract, 28 March 1798; TNA, WO 1/86, Richard McNully Contract, 7 May 1798.

${ }^{89}$ G. Friedman, "The Heights of Slaves in Trinidad," Soc. Sci. Hist. 6 (1982), 487; R. Floud, K. Wachter, and A. Gregory, Height, Health, and History: Nutritional Status in the United Kingdom, 1750-1980 (Cambridge: Cambridge University Press, 1990), 114.

${ }^{90}$ TNA, WO 1/83, Vaughan to Dundas, 25 April 1795.

${ }^{91}$ TNA, WO 1/86, Instructions for the Officers and Medical Staff...to Inspect the Men raised for Government by James Bontein; TNA, WO 1/90, Trigge to Dundas, 20 November 1800; R. Sheridan, Doctors and Slaves: A 
Medical and Demographic History of Slavery in the British West Indies, 1680-1834 (Cambridge: Cambridge University Press, 1985), 132.

92 TNA, WO 1/83, Vaughan to Dundas, 18 April 1795; N. Stepan, “Biology and Degeneration: Races and Proper Places," in Degeneration: The Dark Side of Progress, ed. J. Chamberlin and S. Gilman (New York: Columbia University Press, 1985), 97.

${ }^{93}$ Harrison, Medicine, 108; ibid., 94.

${ }^{94} \mathrm{C}$. Willyams, An Account of the Campaign in the West Indies, in the Year 1794 (London: printed for T. Bensley by G. Nicol, 1796), Appendix 2; Duffy, Soldiers, 223.

95 Duffy, Soldiers, 67.

96 On prior military experience among slaves, see J. Thornton, “African Soldiers in the Haitian Revolution," J. Carib. Hist. 25 (1991).

97 TNA, CO 318/13, Dundas to Grey, 8 December 1794.

98 TNA, CO 137/98, Portland to Balcarres, [n.d.] August 1797.

99 TNA, WO 1/83, Vaughan to Dundas, 31 January 1795.

${ }^{100}$ Maurice, Diary, 240.

101 TNA, WO 1/88, Johnstone to Dundas, 7 June 1798, Private.

${ }^{102}$ R. Buckley, “Brigadier-General Thomas Hislop's Remarks on the Establishment of the West India Regiments - 1801", J. Soc. Army Hist. Res. 58 (1980), 221.

${ }^{103}$ G. Pinckard, Notes on the West Indies, vol.3 (London: Printed for Longman, Hurst, Rees, and Orme, 1806), 189-193

${ }^{104}$ Buckley, Slaves, 37-38.

105 J. Handler, “'Memoirs of an Old Army Officer': Richard A. Wyvill's Visits to Barbados in 1796 and 1806-7," J. Barb. Mus. Hist. Soc. 35 (1975), 27.

106 TNA, WO 1/86, Bowyer to Dundas, 9 September 1798.

${ }^{107}$ Charters, “Making bodies modern,” 229.

${ }^{108}$ C. Wickremesekera, 'Best Black Troops in the World': British Perceptions and the Making of the Sepoy 17461805 (New Delhi: Manohar, 2002), 181-83.

109 TNA, WO 1/84, Myers to Irving, 10 September 1795.

110 Buckley, Slaves, 144. 
111 TNA, WO 1/88, Johnstone to Dundas, 7 June 1798, Private.

${ }^{112}$ A. B. Ellis, History of the First West India Regiment (London: Chapman), 91-92.

113 Buckley, Slaves, 127-129; ibid., 76-77.

114 Ibid., 33; Buckley, “Hislop's Remarks," 222.

${ }^{115}$ Buckley, The British Army in the West Indies: Society and the Military in the Revolutionary Age (Gainesville: University of Florida Press), 121.

116 TNA, WO 1/90, Trigge to Dundas, 20 November 1800.

117 TNA, WO 1/89, Dundas to Trigge, 24 September 1800.

118 J. Hunter, Observations on the Diseases of the Army in Jamaica (London: printed for G. Nicol, 1788), 23-24; ibid., 308-9. 